\title{
AGAMA DI RUANG PUBLIK POLITIK
}

\author{
M. Dawam Rahardjo \\ Rektor Universitas Proklamasi (UP) 45 Yogyakarta
}

\begin{abstract}
The question of the role of religion in the public
\end{abstract} sphere of politics is because of its history, the three monotheist religions, which is also called the Abrahamic religions. Judaism, Christianity and Islam, and even Hinduism and Buddhism, in maintaining their existences and developments, always get into and even form their own power in a country. Indonesia is a secular nation state, which is not based on any particular religion as a political ideology, and yet its people are multireligious. Even though the country is not based on religion, but religion has become a source of inspiration in its constitution, namely UUD (Undang Undang Dasar) 1945. On the one hand, people and the state are in unity for mutual support or mutual need. The state cannot be formed without people as its base. On the other hand, people need the state to protect the society.

Constitution is needed to control the state and its leader. On the one hand this constitution curbs the power of its leader; and on the other hand it guarantees the fulfillment and the protection of civil rights that stem from human rights. The triangle of these institutions is a reality in the current modern world, especially in Indonesia, where religion has an important role, even though in Europe the stand and the role of religion is in the declining stage due to secularization and secularism principle. Yet the relationship of these three institutions in the 
current modern context cause a complex issues related to the boundaries of these three institutions. What are the principles that can continuously connects these three so that justice as the main principle can be uphold between the triangle of society, state and religion?

KEYWORDS: religion, public sphere, nation, civil rights, human rights

ABSTRAK: Persoalan tentang peran agama di ruang publik politik adalah karena dalam sejarahnya, ketiga agama monoteis, yang disebut juga agama Abrahamik itu, yaitu Yahudi, Kristen maupun Islam-bahkan juga Hindu dan Buddha, dalam memelihara eksistensi dan perkembanganmya, selalu mengakses dan bahkan membentuk sendiri kekuasaan negara. Indonesia adalah sebuah negara bangsa (nation state) yang sekuler, artinya tidak didasarkan pada agama tertentu sebagai ideologi politik, namun masyarakatnya multi-religius. Tapi walaupun negara tidak didasarkan pada agama, namun agama menjadi sumber inspirasi dalam konstitusinya, yaitu UUD (Undang Undang Dasar) 1945. Pada sisi lain, masyarakat dan negara juga merupakan satu kesatuan yang saling mendukung atau membutuhkan. Negara tak mungkin terbentuk tanpa basis masyarakat. Sebaliknya, masyarakat membutuhkan negara untuk melindungi masyarakat itu sendiri.

Untuk mengendalikan negara dan kepala negara diperlukan konstitusi. Pada satu pihak Konstitusi ini 
membatasi kekuasaan pemimpin, dan di lain pihak menjamin dipenuhi dan dilindunginya hak-hak warga negara (civil rights) yang bersumber pada hak-hak azasi manusia (human rights). Segi tiga lembaga itu sudah merupakan kenyataan dunia modern dewasa ini, khususnya di Indonesia di mana agama mempunyai kedudukan penting, walaupun di Eropa, kedudukan dan peranan agama sudah mengalami kemerosotan (the decline of religion) akibat sekularisasi dan dianutnya azas sekularisme. Namun hubungan antara ketiganya dalam konteks kemodernan dewasa ini menimbulkan masalah yang tidak sederhana, menyangkut batas-batas ketiga lembaga itu. Dengan prinsip apa saja ketiganya saling berhubungan agar keadilan sebagai prinsip utama relasi segitiga masyarakat, negara dan agama itu bisa ditegakkan.

KATA KUNCI: agama, ruang publik, negara, hak-hak warga negara, hak-hak azasi manusia

\section{I}

Agama dan masyarakat bagaikan ikan dan air, dua hal yang tak bisa dipisahkan. Keduanya lahir dan berkembang hampir bersamaan. Agama yang pada dasarnya adalah bangunan nilai-nilai yang dilandasi atau bersumber pada suatu kepercayaan supernatural itu, kemudian menjadi normanorma, adalah sumber kelahiran suatu masyarakat, sebab norma-norma, sebagai ketentuan tentang apa yang dilarang dan yang diperbolehkan untuk dilakukan, adalah pedoman perilaku orang seorang atau masyarakat. Karena itu, maka 
masyarakat membutuhkan norma-norma untuk bisa tumbuh dan berkembang. Sebaliknya, norma-norma lahir untuk mengatur pergaulan antara sesama manusia dan antara manusia dan makhluk lainnya atau alam semesta yang merupakan lingkungan hidup manusia.

Selanjutnya, agar agama yang sudah berwujud norma dan masyarakat dapat bersama-sama saling mendukung dan mengisi berdasarkan fungsinya masing-masing, diperlukan lembaga kepengurusan yang bertugas mengurus kepentingan dan kebutuhan masyarakat. Menurut Rousseau (1712-1778), demi kelestarian suatu masyarakat, para anggota masyarakat bersepakat untuk memberikan sebagian hak-hak mereka kepada mereka yang akan mengatur masyarakat atau suatu pengurus, ${ }^{1}$ yang dalam Al Qur'an, surat An-Nisaa (4:59) diistilahkan dengan "ulil amri". Kepada pengurus atau ulil amri itulah, setiap individu harus taat, karena ketaatan itu adalah merupakan persetujuan bersama-sama yang berdasarkan suatu prinsip sentral yang disebut oleh John Rawls (1921-2002) sebagai keadilan (justice) dan prinsip-prinsip lainnya yang merupakan nilai-nilai keutamaan atau virtue ${ }^{2}$ yang dalam $\mathrm{Al}$ Qur'an disebut al khair. Itulah, menurut Rousseau persetujuan masyarakat (social contract).

${ }^{1}$ Jean-Jacques Rousseau, The Social Contract (New York: Hafner Press, 1974), 14-15.

${ }^{2}$ Lihat John Rawls, A Theory of Justice (Cambridge: Harvard University Press, 1971), 11-13. 
Hasil dari persetujuan masyarakat itu disebut masyarakat sipil (civil society), sebuah struktur yang sifatnya mandiri dan berswadaya dan karena itu secara eksistensial, bebas. Masyarakat seperti inilah yang dicita-citakan oleh Abraham atau Ibrahim, bapak tiga agama monotheis Timur Tengah: Yudaisme, Kristianisme dan Islam. Sekalipun demikian, dalam sejarahnya masyarakat bebas itu selalu mengalami konflik, karena adanya perbedaan kepentingan dan persaingan di antara individu dan kelompok yang menyebabkan pelanggaran norma. Karena itu maka Hegel (1770-1831) meramalkan bahwa masyarakat sipil itu pada suatu ketika akan hancur dari dalam. Sebab, anggota masyarakat hanya direkatkan oleh etika sehingga, dalam istilah Hegel, hanya merupakan komunitas etik (ethical community). ${ }^{3}$ Struktur etika atau nilai itu jika dijalankan atau berlaku secara konsisten, akan membentuk kebudayaan. Menurut St. Takdir Alisyahbana, (1908-1994) dalam masyarakat sederhana atau primitif, yang menonjol adalah tiga nilai, yaitu nilai kepercayaan atau agama, nilai solidaritas dan nilai seni. ${ }^{4}$ Baru kemudian lahir atau datang dari luar, nilai kuasa termasuk nilai hukum, yang membentuk negara. Dalam perkembangannya kemudian, akan lahir nilai pengetahuan dan nilai ekonomi. Itulah yang berkembang dalam komunitas Arab-Islam dan juga Indonesia. Menurutnya,

${ }^{3}$ Stephen Crites, Dialectic and Gospel in the Development of Hegel's Thinking (Pennsylvania: Pennsylvania University Press, 1998), 408.

${ }^{4}$ Sutan Takdir Alisjahbana, Perkembangan Sejarah Kebudayaan Indonesia: Dilihat dari Jurusan Nilai-Nilai (Jakarta: Idayu, 1975), 9 - 10. 
nilai kuasa dibawa atau datang dari budaya India, dan nilai ekonomi dan ilmu-teknologi (iptek) dibawa oleh Islam dan kemudian Barat-Eropa.

Agar etika dan norma-norma itu tidak dilanggar, maka diperlukan transformasi etika dan norma menjadi hukum positif yang harus ditaati dan mengandung sanksi jika hukum itu dilanggar. Yang melakukan transformasi itu adalah lembaga yang disebut negara (state). Selain melahirkan hukum positif, negara juga berfungsi menjamin berlakunya dan ditaatinya hukum, demi menjaga kelestarian dan keutuhan masyarakat, Itulah sebabnya, maka semua agama besar pada akhirnya akan membentuk kekuasaan. Hal ini terjadi pada tiga agama Timur Tengah: Yudaisme, Kristianisme, Islam, serta dua agama Asia Selatan, Hindu dan Buddha, dan tiga agama Timur Jauh: Konfusianisme, Taoisme dan Shintoisme. Sebelumnya juga sudah terjadi pada agama Zoroaster di Persia dan agama penyembah matahari, Rha di Mesir.

Sebelum ada sistem demokrasi, yaitu negara yang sumber kedaulatannya adalah rakyat atau anggota masyarakat, maka negara didirikan oleh beberapa orang yang salah seorang di antaranya adalah pemimpin atas dasar primus interpares. Karena itu negara dan pemimpin adalah merupakan satu kesatuan. Seseorang itu menjadi pemimpin karena berbagai faktor, misalnya kecerdasan dan pengetahuannya, karena kewibawaan atau kepemimpinannya, karena kekuatannya yang sering didukung dengan senjata atau karena kepribadiannya, yang dalam istilah Ibn Taymiah disebut al syaukah, kekuatan. Setelah seseorang menjadi pemimpin atau memegang kekuasaan, Ibn 
Taymiah mensyaratkan, agar kekuasaan itu dijalankan atas dasar keadilan dan amanah. ${ }^{5}$ Karena itu negara juga harus mengikuti persyaratan itu, adil yang bisa diartikan sebagai seimbang, tidak memihak, atau tidak diskriminatif dan amanah, yaitu dapat dipercaya dalam arti satunya kata dan perbuatan, melaksanakan kewajiban secara bertanggung jawab dan menghormati perjanjian serta dapat diandalkan kemampuannya dalam menjalankan fungsi dan tugasnya.

Dalam negara demokrasi, semua orang itu bisa menjadi calon pemimpin dan kemudian dipilih oleh rakyat. Sedangkan rakyat itu setara dalam hak pilih, apakah ia orang kaya atau tukang becak, apakah ia mahasiswa atau profesor apakah jenderal atau prajurit, asal memenuhi syarat umur yang menandakan kedewasaan dan kemampuan mengambil keputusan atau memilih sesuatu.

Negara baru yang dibentuk oleh seorang pemimpin atau sekelompok masyarakat, selalu didasarkan pada kepercayaan dasar dan struktur nilai tertentu yang telah berkembang pada suatu masyarakat. Dan jika dinilai masih bersifat sederhana dan tidak mencukupi untuk mengatur masyarakat dan negara, maka negara akan mengembangkan kepercayaan dan nilai-nilai itu. Masyarakat dan kerajaan Arab misalnya, memang telah berdiri atas dasar suatu agama tertentu, yaitu Islam-Arab. Tapi karena dirasa kurang dalam menjalankan fungsi negara dan

${ }^{5}$ Ibn Taymiyah, Al-Siyasyah al-Shar'iyah fî Islah al-Ra'y wa al-Ra'iyat. (Beirut: Dar al-Kutub al-'Arabiyat, 1966), 15I. Konsep al-Syaukah dilihat dalam Ibn Taymiyah, Minhajus Sunnah An-Nabawiyyah, Jilid 1, 527. 
kepala negara, maka raja atau khalifah menyuruh mempelajari dan menyerap kebudayaan lain, mula-mula Persia, kemudian Yunani dan Romawi yang telah lebih jauh berkembang. Di masa sekarang, dunia Islam mempelajari dan menyerap budaya iptek dari Barat yang telah jauh berkembang. Tapi, yang diambil bukan agama orang Barat, melainkan ideologi dan iptek yang berkembang di Barat, seperti liberalisme, sosialisme, demokrasi atau republikanisme yang di Indonesia masih bersaing dengan agama sebagai sistem kepercayaan, etika atau ideologi.

Masyarakat dan negara juga merupakan satu kesatuan yang saling mendukung atau membutuhkan. Negara tak mungkin terbentuk tanpa basis masyarakat. Sebaliknya, masyarakat membutuhkan negara untuk melindungi masyarakat itu sendiri. Hubungan antara negara dan masyarakat itu perlu diatur dalam suatu konstitusi yang disusun berdasarkan persetujuan antara pemimpin atau pimpinan dengan individu yang merupakan calon atau sudah menjadi warga negara atau masyarakat ataupun wakil-wakil yang mereka tunjuk atau pilih. Jika tidak maka, yang lahir adalah otokrasi, di mana negara dipimpin dan dijalankan oleh seseorang tanpa kekuasaan yang tidak dibatasi atau sebaliknya suatu anarki, di mana setiap individu memiliki kebebasan mutlak untuk melakukan apa saja. Jika anarki yang timbul, maka yang terjadi adalah apa yang disebut oleh Thomas Hobbes (1588-1679), seorang flsuf sosial Inggris, "homo homini lupus", setiap orang adalah serigala bagi yang lain, dan karena itu Hobbes juga berpendapat tentang diperlukannya kontrak 
sosial agar masyarakat bisa mengatur dirinya secara mandiri dan swadaya. ${ }^{6}$

Perbedaan antara masyarakat yang sudah menjadi civil society dan negara adalah, bahwa masyarakat sipil itu bekerja berdasarkan asas kesukarelaan atau voluntarisme. Sedangkan negara bekerja atas dasar kekuasaan yang berdasarkan kekuatan (power) dan paksaan (coertion) yang menjadi monopoli negara dalam penggunaannya, tapi berdasarkan hukum. Guna menjaga agar tidak terjadi penyalahgunaan kekuasaan yang melanggar hak-hak masyarakat dan warga negara, maka diperlukan aturan hukum (rule of law), utamanya adalah konstitusi yang mengatur perilaku negara dan politik serta hukum pidana yang mengatur perilaku sosial dan perdata yang mengatur perilaku ekonomi.

Konstitusi itu pada dasarnya diperlukan untuk mengendalikan negara dan kepala negara dengan membatasi kekuasaannya di satu pihak dan di lain pihak menjamin dipenuhi dan dilindunginya hak-hak warga negara (civil rights) yang bersumber pada hak-hak asasi manusia (human rights).

Segi tiga lembaga itu sudah merupakan kenyataan dunia modern dewasa ini, khususnya di Indonesia di mana agama mempunyai kedudukan penting, walaupun di Eropa, kedudukan dan peranan agama sudah mengalami kemerosotan (the dicline of religion) akibat sekularisasi dan dianutnya asas sekularisme. Namun hubungan antara ketiganya dalam

${ }^{6}$ Thomas Hobbes, Leviathan. Reprint Edition (New York: Oxford University Press, 2009), 59-60. 
konteks kemodernan dewasa ini menimbulkan masalah yang tidak sederhana, menyangkut batas-batas ketiga lembaga itu. Dengan prinsip apa saja ketiganya saling berhubungan agar keadilan sebagai prinsip utama relasi segitiga masyarakat, negara dan agama itu bisa ditegakkan. Dalam hal ini, John Rawls (1921-2002), seorang pemikir liberal progresif Amerika dari Universitas Harvard, mengusulkan tiga prinsip keadilan dari kacamata warga negara. Pertama, pemenuhan hak sipil seluas-luasnya yang dijamin oleh negara melalui konstitusi. Kedua, ditegakkannya prinsip meritrokrasi di mana setiap individu berhak mendapatkan pekerjaan, menduduki jabatan dan penghasilan berdasarkan keahlian dan ketrampilannya. Ketiga, keharusan agar golongan masyarakat yang paling tidak beruntung tidak boleh tidak tercukupi kebutuhan hidupnya, yaitu sandang, pangan, papan, kesehatan, pendidikan, transportasi dan rekreasi. ${ }^{7}$ Apa yang dilukiskan dalam Q.s. Al Ma'un (107), sebagai sikap menyombongkan diri dan lalai terhadap fakir miskin adalah bentuk kezaliman atau ketidakadilan. Karena itu kemiskinan adalah sebuah kezaliman. Dengan demikian maka keadilan sama dengan kesejahteraan. Jadi masyarakat itu perlu diatur berdasarkan prinsip kesejahteraan sosial bagi seluruh anggota masyarakat.

${ }^{7}$ Rawls, A Theory of Justice, 60-61. 


\section{II}

Indonesia adalah sebuah negara bangsa (nation state) yang sekuler, artinya tidak didasarkan pada agama tertentu sebagai ideologi politik, namun masyarakatnya multi-religius. Walaupun negara tidak didasarkan pada agama, namun agama menjadi sumber inspirasi dalam konstitusinya, yaitu UUD 1945. Contoh yang paling jelas adalah pasal 34 yang mengacu pada surat Al Ma'un yang sejalan dengan nalar publik yang tercermin dalam prinsip ketiga keadilan sebagaimana dikemukakan oleh Rawls. Di sini saja dapat ditarik kesimpulan bahwa agama berperan dan berpengaruh di ruang publik. Namun pengaruh Islam itu dibatasi oleh prinsip-prinsip kebangsaan, yaitu dengan diterimanya Ketuhanan Yang Maha Esa sebagai dasar negara (pasal 29 ayat 1 UUD 1945) di satu pihak, tapi di lain pihak ditolak gagasan agar negara mewajibkan pemeluknya untuk menjalankan syari'at Islam, dengan alasan bahwa jika negara mewajibkan pemeluk Islam menjalankan syari'at Islam, maka hal itu akan bertentangan dengan prinsip kebebasan beragama dan menjalankan ibadah menurut agama dan keyakinannya. Kebebasan beragama itu didasarkan kepada pandangan bahwa hukum agama itu bersifat sukarela yang disebut voluntary law itu. Dari situ timbul masalah yang sekarang ini masih ramai dibicarakan, yaitu dengan cara bagaimana dan seberapa jauh agama bisa atau dibolehkan berperan di ruang publik? Agama memang berkepentingan berperan di ruang publik. Tanpa ruang publik, maka agama akan seperti ikan tanpa air di mana ikan itu hidup. Namun peranan agama di ruang publik ada batasnya dan 
memang perlu dibatasi, justru untuk memelihara prinsip yang paling dibutuhkan oleh agama, yaitu kebebasan (freedom).

Persoalan tentang peran agama di ruang publik politik adalah karena dalam sejarahnya, ketiga agama monoteis, yang disebut juga agama Abrahamik itu, yaitu Yahudi, Kristen maupun Islam, bahkan juga Hindu dan Buddha, dalam memelihara eksistensi dan perkembangannya, selalu mengakses dan bahkan membentuk sendiri kekuasaan negara.

Sebagaimana juga suatu masyarakat selalu berlanjut dengan pembentukan negara. Padahal dalam pengalaman, ketika lembaga kekuasaan telah terbentuk atau seseorang telah menjadi raja atau kepala negara, maka negara justru membatasi bahkan memberangus kebebasan yang dibutuhkan oleh masyarakat, bahkan menindas masyarakat atau rakyat. Demikian pula, ketika agama telah didukung oleh suatu kekuasaan, maka negara justru membatasi kebebasan beragama dan menjalankan ibadah sesuai dengan agama dan kerpercayaannya itu atau melakukan diskriminasi dan pengingkaran hak-hak minoritas. Ironisnya, tindakan kekuasaan itu berasal dari pemuka agama sendiri. Hal ini telah menimpa Yesus Kristus yang dilaporkan, diadili dan dieksekusi dengan penyaliban, justru atas desakan para pendeta Yahudi yang berkolaborasi dengan penguasa Romawi.

Di Indonesia desakan serupa dilakukan oleh Majelis Ulama Indonesia (MUI) agar pemerintah membubarkan aliran Ahmadiyah, atau anjuran Ketua Muhammadiyah dan Ketua MPR agar orang-orang Ahmadiyah mengubah keyakinan mereka atau mendirikan agama sendiri, yang berarti murtad 
dan mengusirnya dari agama Islam dan komunitas Muslim. Dalam kasus ini, negara malah terjebak dalam pengeluaran SKB yang menganjurkan agar Ahmadiyah menghentikan kegiatannya, padahal kegiatan Ahmadiyah sangat bermanfaat bagi masyarakat dan Ahmadiyah adalah organisasi pasifis dan tidak mau melawan pemerintah di seluruh dunia. Sehubungan dengan kasus ini, Ahmadiyah punya sikap seperti itu karena menerima paham sekularisme, sebab dengan sekularisme Ahmadiyah memiliki kebebasan, sebagaimana yang mereka jumpai di Eropa, AS dan Australia, juga di Singapura. Pertanyaan timbul, mengapa organisasi semacam Ahmadiyah justru memperoleh kebebasan di negara-negara non-Muslim, sementara di negara-negara Muslim sendiri, Ahmadiyah mengalami ketidakadilan dan penindasan?

Sumber dari persoalan itu adalah pandangan mengenai kesatuan negara dan agama. Pada awalnya, Nabi memegang kedua otoritas, agama dan negara di satu tangan, matahari di tangan kanan dan bulan di tangan kiri. Kemudian khalifah hanya memegang otoritas politik atau negara, walaupun berdasarkan ajaran agama yang pada waktu itu belum menjadi syari'ah atau sistem hukum yang komprehensif. Dalam perkembangan selanjutnya, ketika telah terbentuk sistem hukum syari'ah, maka mulai tumbuh otoritas agama, namun otoritas agama itu masih berada di bawah otoritas politik, di mana kepala negara dalam sistem Kerajaan Mataram di Jawa, berfungsi sebagai penata agama (panoto-gomo) atau paling tidak pemimpin kaum Muslim (Amir al Mu'minan). Dalam situasi itu, kepala negara adalah juga pengendali otoritas keagamaan, 
namun tidak otoritatif, meminjam istilah Abu Fadl. ${ }^{8}$ Karena itu ada upaya-upaya agar kepala negara tunduk kepada otoritas keagamaan yang otoritatif. Otoritas yang otoritatif itu adalah hukum syari'ah. Dalam istilah sekarang, harus ada supremasi hukum syari'ah. Pandangan ini terutama diartikulasikan oleh Ibn Taymiah, ketika kuasa Arab-Islam sudah hancur yang berarti telah kehilangan otoritas negara. Belakangan, mazhab Syi'ah mengembangkan konsep Wilayah al Faqih, yaitu otoritas kolektif di tangan para ahli syari'ah atau ahli hukum fiqih. Dalam kedua jenis penjenjangan otoritas itu terbentuk sebuah teokrasi. Dalam jangka waktu lama, sebenarnya, kekhalifahan Islam tidak diatur berdasarkan prinsip teokrasi. Dalam kehkalifahan Turki-Osmani, tidak ada otoritas keagamaan yang melembaga, seperti lembaga gereja dalam Kristen. Karena itu khilafah Turki Osmani mampu menyediakan ruang publik bebas yang dinikmati oleh kaum Yahudi yang dirampas kebebasannya di Andalusia, ketika telah jatuh ke tangan otoritas monarki absolut Kristen. Tapi yang berlaku di TurkiOsmani dan sebelumnya di Asndalusia-Islam itu sesuai dengan ajaran Sunnah yang mengatakan "tidak ada ororitas kependetaan dalam Islam". Jadi Islam tidak mengenal otoritas gereja dalam konteks kekristenan.

Pada tingkat organisasi kemasyarakatan, Nahdlatul Ulama (NU) dan Partai Kebangkitan Bangsa (PKB) ternyata

${ }^{8}$ Lihat Khaled M. Abou El Fadl, Atas Nama Tuhan: Dari Fikih Otoriter ke Fikih Otoritatif, terj. R. Cecep Lukman Yasin (Jakarta: PT. Serambi Ilmu Semesta, 2004), 50-57. 
membentuk Dewan Syura, dan Muhammadiyah membentuk Majelis Tarjih yang esensinya adalah otoritas keagamaan yang otoritatif karena berada di tangan para ahli aqidah (kepercayaan) dan syari'ah (norma-norma). Ibn Taymiah mengimbau agar sultan atau khalifah itu tunduk dan taat kepada hukum, yaitu menjalankan dan tidak melanggar syari'ah. Gagasan Ibn Taymiah itu, dalam konteks modern dapat ditakwilkan sebagai konsep negara hukum atau konsep supremasi hukum yang pada waktu itu dibahasakan dengan supremasi syari'ah dan negara berdasarkan syari'ah. ${ }^{9}$ Otoritas semacam ini lebih memberi kebebasan di ruang publik.

Otoritas keagamaan yang melekat kepada khalifah secara tidak otoritatif itu, oleh gerakan Kemalisme Turki, diruntuhkan dan diganti dengan otoritas sekuler yang memisahkan otoritas agama dari otoritas politik. Bahkan lembaga-lembaga keagamaan dimarjinalisasikan dalam kehidupan sehari-hari. Wacana keagamaan di tingkat publik dicegah, sehingga di Turki sekuler, tidak ada partai politik Islam. Tapi pada masa awal Turki sekuler, hanya ada satu partai politik. Tapi pada masa Presiden Ismet Inonu (1884-1973), pengganti Kemal Attaturk (1881-1938), mulai lahir partai oposisi, bahkan partai oposisi ini bisa menang dalam pemilihan umum dan duduk dalam pemerintahan. Namun kerangka ideologi-politiknya tetap sekuler. Kesekuleran itu sudah melembaga dalam

${ }_{9}^{9}$ Anthony Black, Pemikiran Politik Islam: Dari Masa Nabi Hingga Masa Kini, Terj. Abdullah Ali dan Mariana Ariestyawati. (Jakarta: Serambi, 2001), 294-295. 
konstitusi dan dijaga oleh kaum militer, sebagai pengawal konstitusi sekuler. Dari jurusan oposisi ini mulai tumbuh aspirasi Islam, walaupun tidak dilembagakan secara resmi dalam partai Islam. Aspirasi makin mengemuka dalam Partai Refah atau Partai Keadilan. Ketika Partai Refah ini tampak mulai eksplisit aspirasi keagamaanya, misalnya dalam orientasi politik luar negeri yang bekerja sama dengan negara-negara Arab-Islam, maka pemerintahan partai Refah di bawah kepemimpinan Erbakan, dijatuhkan dari tampuk kekuasaan oleh kaum militer. Hal yang sama terjadi di Aljazair ketika FIS berhasil memenangkan pemilihan umum secara demokratis. Tapi aspirasi Islam di Turki itu tidak surut malahan mengalami revitalisasi melalui Partai Keadilan dan Pembangunan (PKP), di bawah kepemimpinan Erdogan. Tapi partai ini tetap tidak keluar dari pagar sekularisme dan bahkan mendukung masuknya Turki ke dalam Uni Eropa.

Partai itu mencoba menghidupkan syari'ah dimulai dengan menghidupkan simbol-simbol keislaman seperti kebebasan perempuan Muslim untuk mengenakan jilbab. Jadi usaha umat Islam meraih ruang publik adalah melalui politik identitas sebagai gerakan kebudayaan. Hanya saja, masyarakat Muslim Turki belum memiliki civil society sebagai ruang publik yang independen dari intervensi negara. Hal ini antara lain karena tradisi etatisme yang mencegah perkembangan ekonomi pasar bebas. Karena itulah maka PKP mendukung sistem pasar bebas dan globalisasi.

Dengan demikian, ketika ruang publik politik masih sulit diakses oleh komunitas Muslim, maka komunitas Muslim 
berusaha memasuki ruang publik kebudayaan dan ruang publik ekonomi. Di Indonesia, umat Islam juga mengalami serangkaian kegagalan dalam meraih peranan dan posisi dalam arena publik politik. Misalnya kasus kegagalan meraih suara yang proporsional dengan jumlah pemeluk Islam, secara nasional maupun regional. Tapi sejak reformasi, Islam mulai bangkit lagi meraih ruang publik politik, melalui legislasi peraturan daerah (perda) syari'ah yang sekarang ini mencapai jumlah tak kurang dari 100 perda syari'ah di seluruh Indonesia. Di masa lalu, gerakan politik Islam telah berhasil merebut ruang publik politik, yaitu dalam UU Perkawinan dan UU Pendidikan. Beberapa waktu yang lalu, kekuatan Islam berusaha mengesahkan RUU Pornografi dan Pornoaksi, tetapi mula-mula mengalami kegagalan karena menimbulkan tentangan dari sejumlah lembaga swadaya masyarakat (LSM) yang menganut paham kebebasan kebudayaan, tetapi kemudian berhasil melalui kekuatan politik di parlemen. Sementara itu berbagai gerakan Islam berhasil melancarkan politik identitas dalam ruang publik kebudayaan, misalnya dalam sosialisasi jilbab yang pada mulanya mengalami hambatan ketika jilbab memasuki ruang publik sekolah yang masuk ke dalam wilayah kebudayaan itu.

Partai Islam juga mengalami kemajuan dalam kasus raihan suara yang diperoleh oleh Partai Keadilan Sejahtera (PKS), terutama di wilayah Jabodetabek yang berada di pusat republik. Dan juga memenangkan pemilihan kepala daerah (pilkada) di beberapa daerah. Tokoh PKS bahkan berhasil menduduki kursi kabinet sejak reformasi. Hal ini disebabklan 
karena penampilan PKS sebagai partai yang berkarakter, bersih dan didukung oleh kalangan terpelajar. Ketika telah meraih kekuasaan, PKS berusaha memperjuangkan berlakunya syari'at Islam, misalnya terjadi di Depok, ketika tokoh PKS berhasil menduduki jabatan walikota.

Namun banyak kalangan masih curiga, apakah PKS, jika memenangkan pemilu dan memegang kekuasaan, baik di legislatif maupun eksekutif, yang berarti telah bermain dalam aturan demokrasi, akan melanggar prinsip sekularisme? Jika itu terjadi bukan tidak mungkin, PKS akan menghadapi masalah kebangsaan sebagaimana yang terjadi pada Partai Refah-Turki, setidak-tidaknya akan menimbulkan konflik dengan golongan militer sebagai pengawal konstitusi dan golongan kebangsaan. Langkah dan jurus PKP sebagai upaya Islam meraih ruang publik bisa dijadikan acuan.

Upaya agama meraih ruang publik dilakukan dengan sukses di bidang ekonomi, yaitu ketika Islam menawarkan konsep keuangan dan perbankan Islam. Upaya ini sebenarnya berasal dari konspirasi para intelektual Muslim lulusan universitas-universitas Barat, untuk menyalurkan dana petrodolar dengan cara syari'ah. Di sini tergabung upaya perkembangan ekonomi dengan politik identitas. Upaya itu menampakkan keberhasilannya di Malaysia dan Indonesia, walaupun kemajuan Indonesia jauh tertinggal atau upaya Malaysia lebih berhasil dari Indonesia sebagai akibat keberhasilan kelompok keuangan Muslim meraih ruang publik, dalam bentuk legislasi hukum syari'ah. Di Malaysia, setiap fatwa syari'ah dari Dewan Syari'ah selalu didukung dengan 
legislasi hukum positif. Sedangkan di Indonesia produk murabahah (pembiayaan atau pinjaman dalam perbankan konvensional, dengan metode mak-up sebagai pengganti bunga) dan raihan terkena pajak ganda, sehingga merugikan bank dan nasabah, karena tidak didukung oleh legislasi hukum syari'ah, namun pajak ganda itu akhirnya dihapus juga atas dasar rasionalitas ekonomi, bukan karena alasan keagamaan. Namun usaha meraih ruang publik dari pihak perbankan syari'ah tetap memiliki peluang. Faktor kelemahannya di Indonesia terletak dari lemahnya pelobi perbankan ke pemerintah dan parlemen. Lembaga keuangan syari'ah juga memiliki peluang untuk melegislasikan UU Perbankan dan Keuangan Syari'ah, tapi kemudian UU Perbankan Syariah berhasil pula direalisasikan secara demokratis. Hal ini sangat tergantung dari kemampuan menyusun paper akademis dan kemampuan legislasi yang seharusnya dimiliki oleh partai-partai Islam semacam PKS. Karena tidak didukung oleh legislasi syari'ah, maka perbankan syari'ah di Indonesia telah gagal mencapai target nilai aset sebesar 5\%, sementara Malaysia telah mencapai 30\% dari total aset perbankan nasional.

Di Turki, PKP ketika berhasil menduduki lembaga kekuasaan di parlemen maupun eksekutif, telah berhasil memajukan perekonomian Turki, sehingga Turki akan bisa meraih status negara Eropa dari segi perkembangan ekonomi dan tingkat pendapatan per kapita. Keberhasilan PKP meraih ruang publik politik bisa menjadi acuan bagi partai-partai politik Islam yang seharusnya bersatu menjadi partai yang lebih besar. Selain PKB dan PAN, masih bisa ditambah lagi satu 
partai Islam yang mengacu pada PKS sebagai hasil merger mengikuti tendensi perusahaan-parusahaan keuangan dan sektor riiil untuk melakukan merger. Dengan perkataan lain, agama bisa memasuki ruang publik melalui rasionalisasi dan demokratisasi dalam proses diskursus.

\section{III}

Sejarah agama-agama dan penyebarannya menunjukkan bahwa agama telah melahirkan suatu masyarakat dan komunitas baru, tapi kemudian masyarakat itu membutuhkan otoritas politik yang disebut negara. Hegel dan Marx mempunyai prediksi mengenai masyarakat dan negara. Hegel berpendapat bahwa civil society yang hanya merupakan komunitas etik (ethical community) itu, tidak akan bertahan karena mengandung konflik internal. Akhirnya masyarakat sipil akan bubar dan dicaplok oleh negara yang mampu menegakkan hukum. Dari perspektif ini dapat dipahami pendapat Ibn Rusyd ${ }^{10}$ tentang perlunya raja dengan kekuasaan absolut yang disebut absulutisme dalam konteks Abad Pertengahan Kristen maupun Islam. Mengacu pada pandangan Ibn Rusyd yang lain dan pandangan Ibn Taimiah, maka kekuasaan raja yang absolut itu dapat digantikan dengan konsep negara hukum yang mengakui supremasi hukum. Supremasi hukum itu dalam konteks negara-monarki, di zaman modern dijelmakan dalam bentuk monarki

${ }^{10}$ Black, Pemikiran Politik Islam, 236-237. 
konstitusional seperti yang terjadi di Inggris dan Belanda.

Sebaliknya Marx berpendapat bahwa justru negara dalam hal ini negara kapitalis, karena kontradiksi dalam masyarakat kapitalis, khususnya perjuangan kelas antara kelas kapitalis dan proletar, akan bubar. "The withering away of state". ${ }^{11}$ Dari kehancuran negara itu maka apabila telah dapat dihapuskan kelas-kelas dalam masyarakat, maka yang lahir adalah masyarakat komunis yang mandiri yang tak memerlukan lagi negara.

Dalam bukunya "Democracy in America" (1833), filsuf sosial Prancis, Alexis Toqcuiville mengamati bahwa demokrasi bisa berkembang baik di AS, karena dukungan civil society yang ditopang oleh oraganisasi-organisasi sukarela (voluntary association) atau organisasi swadaya masyarakat dalam versi Indonesia. Di antara organisasi-organisasi sukarela itu yang terpenting adalah gereja-gereja dan komunitas religius. Organisasi ini, adalah sumber kebudayaan yang menjadi perekat masyarakat di tingkat akar rumput maupun elite. ${ }^{12}$ Dewasa ini, gereja makin kuat di AS, sementara itu agama formal di Eropa mengalami erosi. Di Eropa, peranan agama formal telah digantikan oleh etika modern yang dikembangkan

${ }^{11}$ Withering away of the state, kalimat ini pertama kali muncul dalam buku karya sahabat dan teman seperjuangan Marx, Friedrich Engels Herrn Eugen Dührings Umwälzung der Wissenschaft (1878) yang dalam edisi Bahasa Inggris diterbitkan dengan judul Anti-Duhring: Herr Eugen Duhring's Revolution in Science (1878).

${ }^{12}$ Lihat Alexis Tocqueville, Democracy in America. (New York: Literary Classic of US inc., 2004), 36-37 dan 197-223. 
melalui wacana filsafat. Sebaliknya di AS, agama memang disingkirkan di wilayah publik, namun agama, melalui lembaga gereja, justru berkembang yang didukung oleh budaya karitas dan filantropi. Tapi agama itu tetap memperoleh ruang publik, melalui gereja dan para pengkhotbah. Di AS, agama masih punya pengaruh di ruang publik politik, terbukti dari keberhasilan menolak UU liberal-progresif, misalnya mengenai isu aborsi atau LGBT (lesbian, gay, by-seksual dan trans-seksual) yang dimanfaatkan oleh George W. Bush Jr, dalam pemilu mengalahkan Al Gore yang liberal-progresif itu.

Dengan merosotnya kedudukan dan peranan agamaagama formal, dan berkembangnya pluralisme, maka lahir agama publik (public religion) dan agama sipil (civil-religion) yang berkembang dari etika. Jika di Eropa, agama meraih ruang publik lewat etika, maka di AS dan Kanada, agama meraih ruang publik politik lewat agama publik yang sebenarnya merupakan sinkretisme antara agama-agama dan antara agama dan filsafat. Dari agama publik itu muncul misalnya konsep mengenai masyarakat baik (good society) yang dalam al Qur'an disebut al khair al ummah.

Di AS, etika yang bersumber pada agama, telah meraih ruang publik melalui konsep etika bisnis yang dikembangkan oleh para pendeta sarjana. Dalam konteks masyarakat kapitalis, etika bisnis berperan memanusiawikan kapitalisme. Etika bisnis ini merupakan alternatif terhadap hukum yang mengatur ekonomi, sebagaimana berkembang dalam neoliberalisme Jerman awal pasca-Perang Dunia II mendampingi rekonstruksi ekonomi Eropa Barat. Etika bisnis ini hampir 
menggantikan ilmu manajemen. Paling tidak, etika bisnis telah memanusiawikan manajemen ilmiah. Etika bisnis tidak memerlukan legislasi menjadi hukum positif tapi bekerja sebagai budaya ekonomi yang disebut juga budaya perusahaan (corporate culture). Di lingkungan Islam, agama memasuksi ruang publik ekonomi atau pasar (market) melalui hukum dalam bentuk ekonomi hukum (legal economics), sedangkan di lingkungan Kristen melalui etika bisnis dalam perekonomian kapitalis yang bersumber dari etika Protestantisme (Protestant Ethics).

Dalam zaman sekularisme ini, ternyata agama masih punya peluang untuk meraih ruang publik, melalui agama publik. Menurut Cassanova, agama publik ini lahir melalui ensiklik-ensiklik Gereja Katolik Roma. Di ruang publik ini Gereja Katolik, melalui teologi perdamaiannya, telah berperan penting dalam politik perdamaian dunia.

Juga dalam agama Katolik yang paling parah mengalami proses sekularisasi, agama tampil perkasa melalui agama publik. Di antara yang paling menonjol adalah konsep teologi pembebasan (liberation theology) yang lahir di Amerika Latin yang merasa paling dalam dan langsung dalam cengkeraman kapitalisme dan Neo-liberalisme AS. Dan baru-baru ini, dengan mengusung teologi pembebasan, Michelle Bachelet terpilih menjadi Presiden Chili yang memakai gaya politik yang berbeda dari Hugo Chavez (1954-2013) dari Venezuela dan Evo Morales (1959) dari Bolivia yang lebih kiri-radikal dan Marxis itu. 
Dalam kasus meraih ruang publik ekonomi, komunitas Muslim telah menempuh suatu prosedur tertentu dengan sukses. Pertama, melalui rasionalisasi fiqih mu'amalah berdasarkan kerangka teori ekonomi. Dari sini lahir berbagai pemikiran dan makalah akademis (academic paper) sebagai latar belakang rencana UU. Ternyata ditemukan bahwa doktrin yang paling menonjol adalah larangan riba atau pembungaan uang. Dalam wacana ini dilakukan pendalaman pengertian tentang hakekat riba dan pengaruhnya terhadap kehidupan ekonomi. Kedua teorisasi mengenai pengelolaan dan pengembangan modal. Kebetulan, dunia Islam memiliki keunggulan komparatif di bidang keuangan, yaitu diperolehnya dana dari eksploitasi minyak dan gas bumi yang kebetulan terdapat di banyak negara Muslim, terutama di Timur Tengah dan Asia Tenggara. Wacana ini kemudian dipublikasikan dan didiskusikan di lingkungan akademi, sehingga timbul kajian mengenai teori keuangan Islam ini di berbagai universitas di Barat, misalnya Universitas Oxford di Inggris, Universitas Harvard AS, dan Wolongong, Australia, sehingga menjadi bahan kajian dan diajarkan sebagai mata kuliah baru di bidang ekonomi. Proses rasionalisasi ini diikuti dengan objektivikasi yang didasarkan oleh penalaran moral (moral reasoning) dan penalaran publik (public reasoning). Objektivikasi ini dilakukan pula dengan melakukan penelitian empiris terutama mengenai lembaga-lembaga yang bisa melaksanakan prinsip keuangan Islam yang non-ribawi itu.

Setelah ditemukan dan dirumuskan konsep lembaga keuangan Islam, terutama perbankan, maka dilakukan 
pelembagaan keuangan Islam, yaitu bank Islam yang di Indonesia disebut bank syari'ah. Maka mulailah produk perbankan Islam itu ditawarkan ke pasar. Pada awalnya dijumpai banyak hambatan, termasuk keraguan masyarakat bisnis. Tapi akhirnya diperoleh pengalaman, ketika Bank Mu'amalat Indonesia (BMI) telah dioperasikan sejak 1992, telah terjadi kerugian-kerugian dan kesulitian-kesulitan permodalan, ketika simpanan-simpanan telah terhimpun. Sebagian saham ini terpaksa dijual ke Bank Pembangunan Islam (BPI) yang berpusat di Jeddah. Dengan suntikan permodalan ini dan perbaikan manajemen, maka eksperimen perbankan ini menunjukkan keberhasilan, antara lain berkat pengawasan dari otoritas moneter, Bank Indonesia.

Sejak awal tahun 2000, ketika Indonesia dilanda krisis moneter, bank syariah justru selamat, karena sistem nonribawinya yang memasang nisbah bagi hasil yang tetap, sehingga terhindar dari negative-spread yang menimpa seluruh perbankan konvensional. Setelah itu bank syari'ah menunjukkan keberhasilannya dengan meningkatnya nilai aset, tabungan dan investasi serta kecilnya persentase kredit macet. Gejala ini menunjukkan diterimanya perbankan syari'ah oleh pasar. Kemajuan ini diiringi oleh legislasi berupa surat-surat keputusan BI dan sekarang terus dikembangkan legislasi perbankan dan keuangan syari'ah di DPR.

Ketika nanti banyak legislasi hukum perbankan syari'ah maka Islam telah meraih ruang publik politik. Di satu pihak legislasi syari'ah banyak ditolak, tetapi legislasi di bidang ekonomi ini mengalami kemajuan. Kemajuan lain tampak pula 
dengan disahkannya UU Wakaf. Namun UU ini belum diujikan ke pasar. Hal ini karena kurang dilakukannya proses rasionalisasi dan objektivikasi konsep wakaf.

Dari sini dapat ditarik kesimpulan mengenai pentingnya proses rasionalisasi dan objektivikasi norma-norma agama. Rasionalisasi ini dilakukan dengan mengembangkan filsafat keagamaan. Sedang proses objektivikasi dilakukan melalui penalaran publik (public reasoning) yang didukung dengan penelitian empiris. Ini menjadi agenda kajian keislaman sebelum agama bisa meraih wilayah publik modern dewasa ini. Masalahnya adalah mungkinkah para pendukung dan penganut agama melakukan rasionalisasi dan objektivikasi itu? Hal ini merupakan hambatan tersendiri, karena pada umumnya kaum pemeluk agama telah merasa mantap memegang ortodoksi keagamaan yang dahulunya telah mengalami proses rasionalisasi dan objektivikasi juga. Karena itu para pendukung agama, khususnya Islam akan terbelah menjadi dua kubu. Pertama yang tetap setia berteduh di bawah rumah ortodoksi, yaitu Ahl al Sunnah wa al Jama'ah, Syi'ah dan Ahmadiyah. Kedua adalah penganut paham reformasi yang ingin berpikir ulang tentang ortodoksi dan menginginkan pembaharuan. Golongan ortodoks tercermin pada kelompok yang menolak liberalisme, pluralisme dan sekularisme yang masih setia pada teks secara harfiyah dan ahistoris atau yang menginginkan purifikasi atau romantisme masa-masa awal perkembangan Islam, yaitu masa generasi Salafi ketika ilmuilmu keislaman berada pada proses formasi sebelum masuk pengaruh Yunani atau Hellenisasi. 
Kaum ortodoks dan puritan melihat bahwa tiga paham baru itu jika dibiarkan akan membahayakan ortodoksi Islam seperti yang sudah dirumuskan dalam paham Ahl Sunnah wa al Jama'ah. Padadoksnya, gerakan melampaui tradisi itu justru lahir dari kalangan tradisional Ahl al Sunnah wa al Jama'ah. Otokritik kalangan tradisional ini muncul karena kesadaran yang muncul dalam pengalaman politik ketika kaum ulama memasuki ruang publik melalui kegiatan politik. Hanya saja, kesadaran tentang keterbatasan ortodoksi Islam memasuki ruang publik itu muncul di kalangan muda. Hal ini terjadi karena kalangan mudalah yang akan meneruskan kegiatan generasi ulama senior meraih ruang publik politik.

Kesadaran pertama muncul ketika generasi muda memasuki publik politik yang plural. Pluralitas itu dilihat tampak makin meluas dalam masyarakat modern, terutama di perkotaan. Sebelumnya pluralitas tampak dalam struktur kebangsaan. Untuk bisa membentuk bangsa yang kuat diperlukan persatuan dalam kebhinekaan, di mana setiap golongan masih bisa memelihara dan mengembangkan identitasnya. Persatuan menghendaki lenyapnya primordialisme, sektarianisme dan lebih-lebih fanatisme sempit. Semua gejala sentrifugal itu harus diatasi melalui pluralisme yang tidak saja melahirkan toleransi tetapi juga interaksi terbuka dengan semangat ta'aruf (saling memahami dan menghargai).

Pluralisme akan mengharuskan sikap keterbukaan dan kebebasan berpikir atau pemikiran liberal. Tapi pemikiran liberal ini diharamkan oleh MUI untuk diikuti. Dalam persepsi 
MUI, liberalisme adalah pemikiran yang lebih mengutamakan akal daripada wahyu, sedangkan menurut MUI dan paham ortodoksi, akal harus tunduk kepada wahyu. Namun dalam teologi dan filsafat ada beberapa pandangan lain mengenai relasi akal dan wahyu, iman dan ilmu pengetahuan. Pandangan yang dominan di kalangan cendekiawan Muslim di Indonesia adalah keseimbangan antara akal dan wahyu dan antara iman dan ilmu pengetahuan. Sedangkan dalam khasanah intelektual Islam terdapat beberapa pandangan yang memandang masalahnya secara lain. Misalnya Al Farabi berpendapat bahwa akal dan pemikiran manusia itu sudah ada sebelum wahyu turun. ${ }^{13}$ Sedangkan Ibn Rusyd berpendapat bahwa akal itu adalah anugerah Allah yang tidak lebih rendah daripada wahyu. Akal diberikan kepada setiap manusia, sedangkan wahyu hanya diturunkan kepada nabi. ${ }^{14}$ Pandangan kontemporer mengatakan bahwa wahyu itu adalah sesuatu yang beku dan mati, sedangkan akal itu terus hidup dan berkembang.

Namun, pemikiran-pemikiran tersebut di atas adalah abstrak, sangat spekulatif dan tidak empiris. Secara empiris, apa yang disebut wahyu itu kenyataannya adalah suatu penafsiran yang berkembang menjadi apa yang baru-baru ini saja disebut pengetahuan kewahyuan (revealed knowledge), bukan wahyu itu sendiri. Kedudukan ilmu kewahyuan itu

\footnotetext{
${ }^{13}$ Harun Nasution, Akal dan Wahyu dalam Islam (Jakarta: Universitas Indonesia, 1983), 17.

${ }^{14}$ Black, Pemikiran Politik Islam, 228-229.
} 
tidak lebih tinggi dari ilmu pengatahuan umum hasil pemikiran manusia. Sementara itu interpretasi wahyu tidak hanya tunggal melainkan beragam dan bersifat spekulatif. Oleh karena itu maka ilmu kewahyuan tidak bisa dianggap sebagai qod'i atau muhkamat (kebenaran yang jelas).

Realitas lain adalah, bahwa ilmu-ilmu kewahyuan itu tidak cukup berkembang sehingga bisa dipakai untuk membangun peradaban. Bahkan produk ilmu kewahyuan itu, misalnya kalam, fiqh, tasauf, tafsir atau hadist sudah ketinggalan zaman dan tidak lagi relevan untuk zaman modern. Karena itu maka ilmu kewahyuan itu tidak bisa diunggulkan dari ilmu pengetahuan umum dan teknologi. Ilmu kewahyuan itu sendiri tidak sampai menjadi teknologi dan manejemen.

Karena itu maka ilmu kewahyuan itu tidak bisa memasuki wilayah publik, kecuali jika sudah mengalami transformasi menjadi filsafat, etika dan ilmu pengetahuan umum yang rasional dan empiris. Maka jalan keluarnya adalah liberalisasi pemikiran keagamaan dan demokratisasi otoritasnya.

Sekalipun ilmu kewahyuan itu telah menjadi ilmu pengetahuan umum yang rasional dan empiris, misalnya telah menjadi ilmu hukum, ilmu politik atau ilmu ekonomi, namun ilmu-ilmu yang dikatakan bertolak dari wahyu itu tidak bisa mendapatkan legitimasi keagamaan. Kebenarannya tidak mutlak, melainkan relatif. Salah satu alasan MUI yang menolak pluralisme adalah menganggap kebenaran itu relatif, seolaholah kebenaran ilmu kewahyuan itu mutlak. Padahal semua hasil pemikiran itu kebenarannya relatif. Yang benar dulu 
belum tentu tetap benar sekarang. Dan apa yang benar sekarang belum tentu benar di masa mendatang. Hal ini lebih aman dari segi aqidah. Tidak ada yang benar mutlak kecuali Allah. Namun pengetahuan mengenai Allah juga tidak berhak atas kebenaran mutlak, tetap relatif. Karena itu maka perlu dilakukan sekularisasi terhadap ilmu pengetahuan, dalam arti ilmu pengetahuan harus dibebaskan dari dogma dan tidak terikat pada ortodoksi apa pun.

Liberalisasi ilmu akan menghasilkan pengetahuan baru. Pengetahuan baru itu pun menimbulkan sikap kritis dan otokritik terhadap diri sendiri dan komunitasnya. Di sini mulai timbul keterbukaan untuk memahami dan belajar dari dan dengan orang lain. Selanjutnya hal itu menimbulkan hasrat untuk lebih bebas berpikir yang berarti tidak mau terbelenggu dalam dogmatisme dan ortodoksi. Keterbukaan dan kebebasan itu pun akan membuka pintu untuk bisa berpikir mengikuti penalaran publik. Dalam kerangka penalaran publik itu agama akan dibawa kepada wacana publik. Proses itulah yang sebenarnya melatarbelakangi timbulnya gagasan tentang Teologi Pembebasan di Amerika Latin, ketika para pemikir agama mulai memahami situasi di Amerika Latin dari kaca mata Marxisme. Maka lahirnya Teologi Pembebasan sebagai salah satu ekspresi agama publik yang berpengaruh di Dunia Ketiga itu. Dari pengalaman itulah pemikir Muslim India, Asghar Ali Engeener (1939-2013), menulis sebuah versi teologi pembebasan dalam perspektif Islam. Karya Asghar Ali adalah sebuah wacana politik Islam di arena publik internasional. 
Setelah gagal memperjuangkan dasar negara Islam dalam konstitusi dan menggunakan negara untuk mewajibkan umat Islam melaksanakan syari'ah, maka upaya Islam untuk menguasai ruang publik masih diteruskan melalui perjuangan partai secara demokratis. Usaha ini telah juga mengalami kegagalan, karena dalam pemilu, semua partai Islam tidak berhasil memperoleh suara yang proporsional dengan jumlah umat Islam di Indonesia, yaitu 87\%. Dengan perkataan lain, partai Islam telah menjadi golongan minoritas dalam struktur kepartaian Indonesia. Sungguh pun demikian, aspirasi Islam dan umat Islam justru bisa diperjuangkan oleh partai-partai politik sekuler. Kepala negara dan wakilnya masih tetap dipegang oleh Muslim, tanpa menentukan dalam konstitusi bahwa presiden dan wakil presiden Indonesia harus Muslim. Di sini masih ditunjukkan pengaruh Islam sebagai agama di ruang publik politik. Tapi hal ini terjadi juga pada agama Kristen di Eropa dan Amerika Utara yang telah jauh mengalami proses sekularisasi, walaupun di seluruh dunia, di mana Islam merupakan agama mayoritas, kepala negara tetap bertahan dipegang oleh Muslim.

Semua itu mengajarkan bahwa pemeluk agama akan merasa tetap perlu menjadi pendukung utama civil society, tapi dalam kondisi yang plural dan mendapat perlindungan dalam sekularisme yang ramah terhadap agama, yang menjamin kebebasan beragama dan menjalankan ibadah menurut agama dan kepercayaannya. Kepentingan agama di ruang publik politik sebenarnya adalah di satu pihak dapat memelihara dan mengembangkan identitas dalam masyarakat yang plural, dan 
di lain pihak untuk mencegah agar tidak terjadi konflik vertikal dan horisontal yang dapat merusak kondisi umat dan bangsa serta menjaga agar agama tetap berperan dan memberi pengaruh terhadap ruang publik pada umumnya. 